\title{
GLL
}

$00=0$ Geomatics, Landmanagement and Landscape No. $3 \cdot 2021,41-52$

\section{LOCATION OF OVERHEAD POWER LINES WITHIN BUKOWE HILLS MESOREGION IN RELATION TO THE ASSESSMENT OF FOREST AREA FRAGMENTATION}

\author{
Paweł Pieńkowski, Marcin Stoltman, Bogusław Zakrzewski
}

\begin{abstract}
Summary
National power grid in Poland requires modernisation, therefore by 2030 numerous actions are scheduled regarding the expansion of the existing network and the construction of new electricity transmission lines (power lines). The planned activities will undoubtedly change the quality of landscape and result in fragmentation of forest habitats, some of which are characterised by high biodiversity and constitute a key element of ecological corridors.

The aim of the present paper was to outline the issue of the impact of the power line corridors on forest habitat fragmentation, as well as to present the GuidosToolbox software (Graphical User Interface for the Description of image Objects and their Shapes) used, among other things, for the determination of the degree of fragmentation of forest habitats. The analysis concerned the Puszcza Bukowa forest, which is a part of the Natura 2000 network and is protected under the Szczecin Landscape Park 'Puszcza Bukowa'. Despite abundant natural assets of the Puszcza Bukowa forest, it was necessary to run many power lines through its area due to location of the forest in the vicinity of the Szczecin agglomeration. The course of power lines contributed to the fragmentation of the discussed forest complex and to the depletion of its interior classified with the GuidosToolbox software as 'Intact'. The software discussed in the present paper may prove useful in the identification of the degree of forest area fragmentation, connected with the course of high-voltage power transmission lines, and in the assessment of the impact of the planned investment projects on biocenoses.
\end{abstract}

\section{Keywords}

high-voltage power transmission lines $\bullet$ habitat fragmentation $\bullet$ landscape fragmentation $\bullet$ landscape analysis

\section{Introduction}

Economic development predominantly based on advanced technologies as well the necessity to remodel the national energy mix towards distributed renewable energy sources, require planning and construction of new electricity power lines. National power grid needs modernisation as the existing transmission and distribution network (established mainly in the 1960s and 1970s) does not meet the increasing current 
carrying capacity. Polskie Sieci Elektroenergetyczne - the transmission system operator in Poland - aims to increase the length of $400 \mathrm{kV}$ power lines by $3701 \mathrm{~km}$ by the year 2030. Additionally, the development of the electric grid is to be accompanied by the investments of the distributing companies managing the transmission lines of 110 $\mathrm{kV}$, among other things. Owing to the necessary increase in operating voltage as a part of the expansion of the national power grid, modernisation of the existing transmission infrastructure is also planned.

New transmission lines are to be run, among others, through forest areas owing to high forestation rate of Poland (29.5\%) and the pressure from the local community to delineate the course of the high-voltage and the highest-voltage transmission lines through wooded areas. This is mainly due to the public's reluctant attitude towards infrastructure projects, concern for their health and fear of lowering the value of real estate owing to environmental risks [Porsius et al. 2015]. Routing the transmission infrastructure through forest areas often allows reducing the negative visual effects due to smaller landscape openness of the wooded areas [Plit and Myga-Piątek 2014]. Therefore, the development will involve creation of new or extending the existing power line corridors within forest areas. The corridors, also known as the buffer zones, are supposed to secure the safety of operation of the national power grid, as well as ensuring protection of people, property, and environment in the direct vicinity of electricity power lines. This is connected with the need to keep woody vegetation at a particular height or a complete prohibition of plantings - owing to the requirements to ensure appropriate short-circuit distance.

There are various technologies for routing the electric grid infrastructure through forest areas. When establishing or modernising power lines (regardless of the voltage they carry), the so-called 'forest pillars' or pillars over the forest are used. The design of the 'forest pillars' is characterised by a minimised distance between the outermost power cables, which allows a reduction in the width of the treeless corridor in comparison with the standard design. The use of pillars over the forest completely eliminates the need to cut down trees to create the aforementioned corridor. The latter solution makes use of higher pillars allowing the location of cables over the treetops and reducing the deforestation only to the area of the pillars' location, thus preventing fragmentation of forest patches. However, despite the employed technology of pillars over the forest, the landscape is dominated by transmission infrastructure, which in forest areas is accompanied by treeless corridors.

The Polish Norms provide detailed technical requirements concerning transmission lines. However, in practice, transmission system operators use corridors of several widths to ensure safe short-circuit distance depending on the transmitted voltage and the structural design of the electricity power line (Fig. 1). The corridors of the highest width are set up for high-voltage and highest-voltage power transmission lines (110 $\mathrm{kV}-400 \mathrm{kV}$ ). The width of the said corridors for lines of voltage $110 \mathrm{kV}$ is $15 \mathrm{~m}$, for $220 \mathrm{kV}-50 \mathrm{~m}$ and $400 \mathrm{kV}-70 \mathrm{~m}$ [Dołowy et al. 2015].

The planned investment projects consisting of constructing new transmission lines will undoubtedly result in the fragmentation of forest habitats generally characterised 
by high biodiversity and constituting key elements of ecological corridors, allowing dispersion of numerous species [Powell and Lindquist 2011, Fuentes-Montemayor et al. 2013].
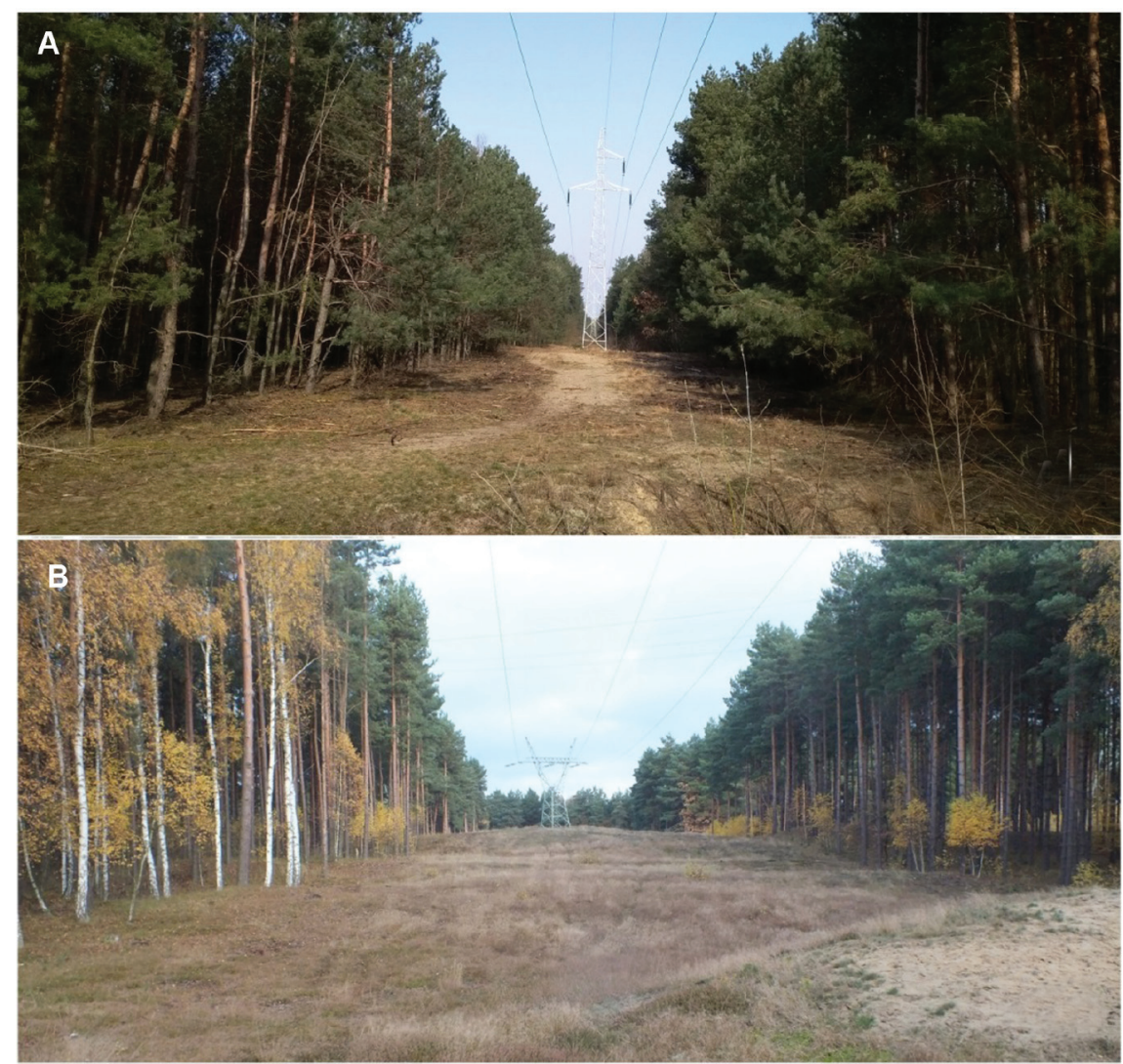

Photo: Authors' own photo, M. Stoltman

Fig. 1. Power line corridors within forest areas under single-rail lines of $110 \mathrm{kV}$ in a triangular configuration (A), and $220 \mathrm{kV}$ running flat (B)

The effect of the fragmentation of forest biocenoses depends on various factors connected with the size of the patches, their shape, and the course of edges. It also depends on ecological tolerance of the species inhabiting the area and the position of a given species in the trophic chain. The linear fragmentation contributes to the increased number of patches and to a decreased area classified as forest interior [Ewers and Didham 2008, Banks-Leite et al. 2010, Xu et al. 2016]. It is also believed to generally result in a decrease in the abundance of stenobiotic species, though it creates favourable conditions for an increase in the abundance of species showing a wide tolerance 
range, characteristic for open and semi-open areas [Baranowska-Janota and RozenauRybowicz 2007].

Paradoxically, the linear fragmentation associated with the creation of corridors and the need to remove woody vegetation creates specific conditions for the development of some species of animals and plants. Numerous studies have shown an increased species richness within corridors, including mosses, lichens, shrubs and synanthropic species [Eldegard et. al. 2015]. The high habitat potential of appropriately managed technological corridors is also indicated for some species of birds [Clarke and White 2008, Askins et al. 2012], bees [Russell et al. 2005], and butterflies [Forrester et al. 2005]. Eldegard et al. [2015] indicated that appropriate management of these spaces increases the possibility of organisms using these corridors as alternative habitats. The results of research projects conducted in Europe show that remodelling the edge zone of tree stand and introducing alternative methods of land management within the power lines corridors contributes to an increase in biodiversity [Poikolainen and Malinen 2020]. In order to minimise the fragmentation of forest patches, it is recommended that electricity power lines should be established over the treetops, that running the lines through forest areas of significant natural value should be avoided, and even that re-routing or bundling of infrastructure should be considered [Nayak et al. 2020].

The actions taken to minimise the environmental impact resulting from the presence of PTL (Power Transmission Line) should be preceded by the analysis of local conditions within the framework of environmental monitoring. The application of geographical information system tools as well as specialised software providing analyses of fragmentation on numerical maps enable the objective assessment of the degree of fragmentation of forest ecosystems, and therefore promote planning the optimum actions to minimise the effect of linear fragmentation on biodiversity [Mancebo Quintana et al. 2010].

There are numerous publications presenting different aspects of the linear fragmentation on forest ecosystems and their biodiversity. Consequently, the planning of new transmission lines should take into account the effect of the investment on the fragmentation of forest areas, particularly those protected ones (under various forms of nature protection) [Yildirim and Nisanci 2010], and consider methods of managing the corridors [Li and Lin 2019].

For this reason, the present paper aims to present the issue of the effect of the course of electricity power lines on the fragmentation of forest ecosystems. The paper additionally presents a sample application of software (GuidosToolbox), which may be useful, among other things, in planning and analysis of the effect of the electric power investment projects on forest habitats.

\section{Object of the study}

The research area covers the Bukowe Hills, located east of Szczecin, on the right bank of the Oder River. The area in question lies on a ridge of push moraine related to the Szczecin phase, and belongs to the Bukowe Hills mesoregion. This small mesoregion 
(123 km2) is predominantly covered with dense beech forest (Puszcza Bukowa), whereas the southern section of the undulated moraine upland is used for agriculture. The Puszcza Bukowa forest is a vital element of the Northern Corridor (KPn) established within the framework of ecological corridors distributed over the European Network of Natura 2000 [Jędrzejewski et al. 2011]. The forest has an outstanding natural value as has been reflected by numerous forms of nature protection established there (Fig. 2). The Puszcza Bukowa forest is protected under the Habitats Directive and the 'Puszcza Bukowa' Szczecin Landscape Park.

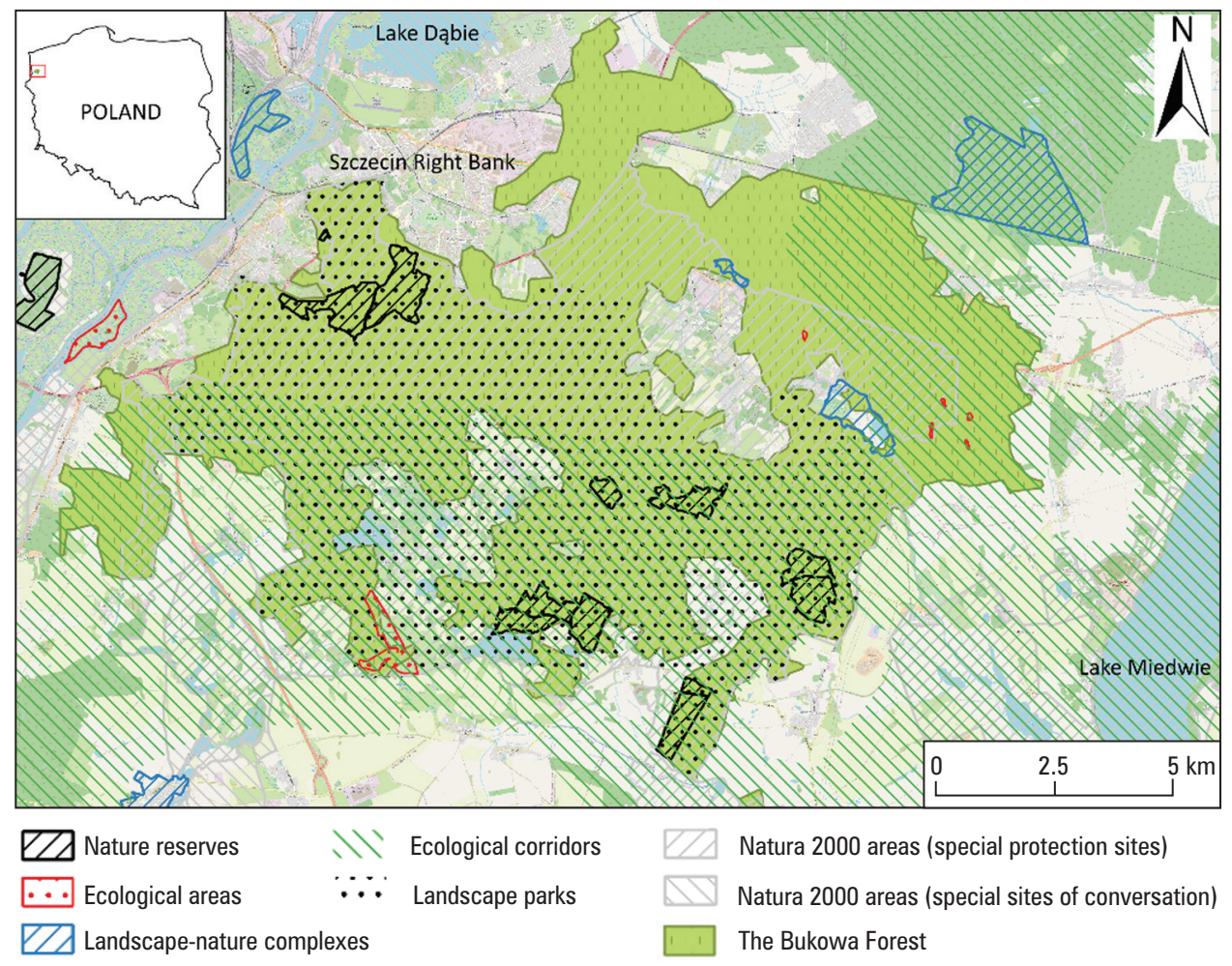

Source: Authors' own study based on the Database of Topographic Objects

Fig. 2. The location of the study object and forms of nature protection

\section{Materials and methods}

To calculate the linear fragmentation of the Puszcza Bukowa complex, a vector map of the Database of Topographic Objects (BDOT) [Journal of Laws of 2011, No. 279, item 1642] was used, from which objects in the 'forest and wooded area' class were extracted. Then the extracted vector layer was converted to raster using the 'vector to raster' Qgis module. 
The fragmentation analysis was conducted on the basis of Forest Area Density (FAD) module being a part of the GuidosToolbox software [Vogt and Riitters 2017]. The FAD module allows for generating maps that illustrate the course of the fragmentation of forest areas. The maps show the division of the area into six classes (I-VI). Class I illustrates forest fragments that are the thinnest, whereas class VI (Intact) represents areas characteristic for forest interior, away from the edge zone. The classes are calculated for five scales of observation, which - according to the developers of the software - can be considered optimum for the assessment of forest fragmentation. When calculating the FAD indicator, a 'moving window' of the following sequence of raster cells was employed: $7 \times 7,13 \times 13,27 \times 27,81 \times 81,243 \times 243$, which - given the size of a raster cell adopted in the present paper $(3 \times 3 \mathrm{~m})$ - corresponds approximately to the following window sizes: 0.04 ha, 0.15 ha, 0.66 ha, 5.90 ha, and 53.14 ha. The size of the windows was adjusted to the scale of the issue under analysis, which should take into account both the size of the analysed forest complex [Bücking 2003] and the extent of the impact of the object which caused the fragmentation [Li and Lin 2019].

Fragmentation classes are determined by the Foreground Area Density (FAD), which is calculated for each raster cell located in the central part of the moving window. This indicator expresses the percentage of raster cells representing forest areas in relation to the whole number of cells within the moving window. The results calculated for particular classes of observations are then generated as a sequence of five maps, as well as the summary map showing all scales of observation - a summary multi-scale image. Determination of the individual classes divided according to the FAD index for one of the five window sizes is presented in Table 1.

Table 1. Form of incidence of forest patches (fragmentation classes) depending on forest area density for one of the selected moving window sizes

\begin{tabular}{|c|c|c|}
\hline Pixel value & Fragmentation class & $\begin{array}{c}\text { Forest area density (FAD) } \\
{[\%]}\end{array}$ \\
\hline 1 & I & $<10$ \\
\hline 2 & II & $10-40$ \\
\hline 3 & III & $40-60$ \\
\hline 4 & IV & $60-90$ \\
\hline 5 & V & $90-100$ \\
\hline 6 & VI & 100 \\
\hline
\end{tabular}

Source: based on Vogt [2018]

The summary map considers the calculations obtained using five different sizes of moving windows and has the same resolution as the individual maps. The raster cell values range from 5 (when the raster attribute value is in fragmentation class I on all five maps) to 30 (when the raster attribute value is in fragmentation class VI on all five 
maps). The method of calculating the Foreground Area Density for the total result map is presented in Table 2 .

Table 2. Diagram of the classification of forest patches, in terms of their fragmentation on the summary map

\begin{tabular}{|c|c|}
\hline Baseline sum & Summary fragmentation class \\
\hline $5-9$ & I \\
\hline $10-14$ & II \\
\hline $15-19$ & III \\
\hline $20-24$ & IV \\
\hline $25-29$ & V \\
\hline 30 & VI \\
\hline
\end{tabular}

The study was carried out in two phases. In the first, the calculation of the FAD indicator covered wooded areas without power lines corridors; in the second, the calculation of the FAD indicator included wooded areas cut with power lines corridors.

\section{Results and discussion}

The linear fragmentation resulting from establishing transmission infrastructure generally leads to negative changes within forest complexes, including the increase in the borderline of forests and causing the so-called edge effect [Rich et al. 1994]. This phenomenon is particularly noticeable within the Bukowe Hills mesoregion where a dense forest complex (the Puszcza Bukowa forest) of an area 12940 ha is located and fragmented with power lines (Table 3 ). Within the forest, high-voltage power lines run at a length of $54.9 \mathrm{~km}$, out of which $30.3 \mathrm{~km}$ cross the area of the ecological corridor, and $28.4 \mathrm{~km}$ cross the protected areas.

Table 3. The length of power lines within the Puszcza Bukowa forest including the protected areas

\begin{tabular}{|c|c|c|c|c|c|}
\hline \multirow{2}{*}{ Voltage } & Total & \multicolumn{2}{|c|}{ Protected areas } & \multicolumn{2}{c|}{ Ecological corridor } \\
\cline { 2 - 6 } & {$[\mathrm{km}]$} & {$[\mathrm{km}]$} & {$[\%]$} & {$[\mathrm{km}]$} & {$[\%]$} \\
\hline $110 \mathrm{kV}$ & 40.1 & 21.6 & 53.9 & 17.5 & 43.6 \\
\hline $220 \mathrm{kV}$ & 8.1 & 3.3 & 40.7 & 7.2 & 88.9 \\
\hline $400 \mathrm{kV}$ & 6.7 & 3.5 & 52.2 & 5.6 & 83.6 \\
\hline
\end{tabular}


One of the methods for the assessment of forest area fragmentation is using FAD indicator. The effect of using 5 scales of observation (representing the adopted size of the moving box) is a summary multi-scale image illustrating the division of the area into particular forest fragmentation classes (Fig. 3). The result of the linear fragmentation, presented in this figure, is the classification of forest areas neighbouring the power lines to fragmentation classes V and IV. Given the selection of the moving window adopted in the present paper, it can be assumed that the corridors belonging to both classes may illustrate the edge affected forest areas. Depending on the route and the voltage of power lines, the width of the corridors indicated on the map extends from 300 to $1000 \mathrm{~m}$ and is comparable to the range of power lines impact as given by other authors [Li and Lin 2019]. The greatest impact of power lines on forest fragmentation, demonstrated by re-classification of areas from class VI to $\mathrm{V}$ and IV, occurs mainly within the area of $110 \mathrm{kV}$ and $400 \mathrm{kV}$ power line branching (Fig. 3B). Linear fragmentation distance between the two patches classified as VI reaches $1500 \mathrm{~m}$.
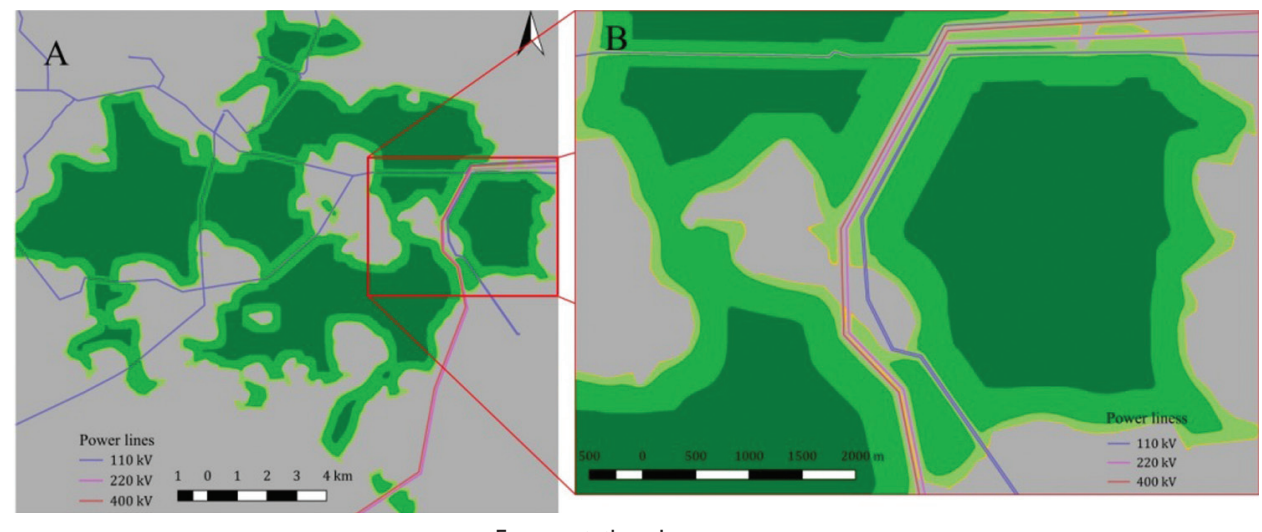

Fragmentation class

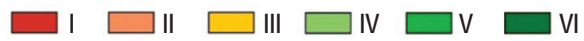

Source: Authors' study

Fig. 3. Summary multi-scale image of fragmentation classes of the Puszcza Bukowa forest, including the course of transmission lines (A) and expansion of its eastern section (B). Fragmentation class: I - Thin, II - Patchy, III - Transitional, IV - Dominant, V - Interior, VI - Intact

The FAD module enables presentation of the share of particular fragmentation classes in the form of a histogram (Fig. 4). It provides a summary of the results obtained for maps generated with the use of five observation classes and a multi-scale image.

The Puszcza Bukowa forest is characterised by a relatively well-developed edge line and the presence of fragments branching from the main forest complex, which depletes the area defined as the interior of the patch [Laurance and Yensen 1991]. Therefore, even without considering the linear fragmentation (Fig. 4A), the share of areas of class VI (intact) in a multiple-scale analysis amounts to $57.8 \%$ of the total area of the 
forest. The course of power lines additionally decreases the area by $6.0 \%$. If we apply the adopted size of the moving window, and even without consideration of the linear fragmentation, the Puszcza Bukowa forest, being a relatively large forest complex, does not demonstrate forest patches or their fragments of the highest isolation degree - class I, whereas the share of areas of class II is negligible (0.01\%).

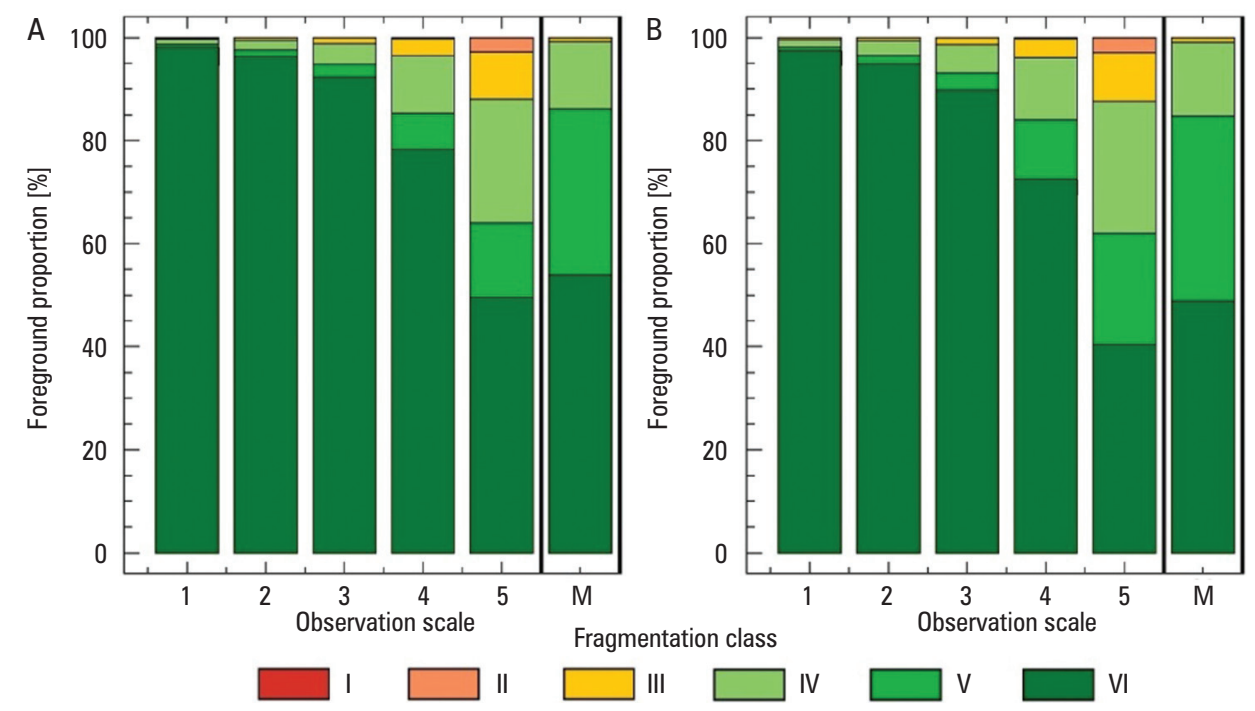

Source: Authors' study

Fig. 4. Differentiation of the share of particular fragmentation classes between forest areas without considering the corridors adjacent to power lines (A), and the area with power line corridors (B)

The concentration of power lines within the Puszcza Bukowa forest is conditioned by its location - the neighbouring Szczecin agglomeration and close vicinity of Morzyczyn electrical power station (approx. $3 \mathrm{~km}$ from the edge of the forest complex). The corridors accompanying the transmission lines within the Puszcza Bukowa forest do not deplete the acreage of the forest significantly, since they constitute only $1 \%$ of its total area, yet they decrease the area classified as forest interior and, consequently, they affect the species of plants and animals showing a preference towards biotopes away from the forest edge [Villard 1998]. The influence of the edge effect on the functioning of the fragmented forest patches to a large extent depends on the structure of the edge of the forest [Collinge and Palmer 2002] which, in the case of transmission lines, has a sharp edge contrasting with the surroundings [Ries et al. 2004] and may aggravate the effect of the fragmentation on forest environment. 


\section{Summary and conclusion}

The development plan for Poland in terms of meeting the present and forecasted demand for electrical power in the years 2021-2030 envisages, among others, increasing the length of transmission lines and modernisation of the existing infrastructure. These actions necessitate the analysis of not only the technical and economic issues, but also the effect of the pressure resulting from the planned investment projects on the environment and quality of the landscape. Particular attention should be given to protected areas and ecological corridors, which include forest areas. The course of transmission infrastructure within forest areas necessitates the creation of corridors, which contribute to the fragmentation of the area of forest patches, among other things. In the analysis of this phenomenon, Geographical Information Systems and specialist ecological software, including GuidosToolbox allowing the assessment of forest fragmentation on the basis of raster maps, prove to be useful. The software was used for the assessment of linear fragmentation of the forest complex included in the 'Puszcza Bukowa' Szczecin Landscape Park. The resolution of maps adopted in the present paper $(3 \mathrm{~m} \times 3 \mathrm{~m})$, determining the size of the pre-defined 'moving windows', enabled graphic presentation of forest fragmentation and classifying the area of the fragments into fragmentation classes as identified in the software application. The Puszcza Bukowa forest is a relatively large forest complex (12940 ha), therefore the share of the area classified as showing the highest fragmentation rate was relatively small. However, it is necessary to consider that in the analysis of smaller patches, linear fragmentation resulting from the course of PLT will show a much greater impact on decreasing the interior of the forest, including the areas classified as Intact. Special attention would also have to be given to the fact that power transmission lines usually run in a straight line. Therefore, the effects of forest fragmentation are smaller than in the case of infrastructure projects with a more varied course.

The software discussed in the present paper may be used to pinpoint the areas (particularly protected areas) in which the course of high-voltage power transmission lines would have the greatest impact on forest fragmentation. In such areas, it would be advisable to implement alternative methods of power line corridor management in order to increase biodiversity, as has been undertaken in numerous projects by national transmission system operators in Europe [LIFE ELIA-RTE 2017].

\section{References}

Askins R.A., Folsom-O’Keefe C.M., Hardy M.C. 2012. Effects of vegetation, corridor width and regional land use on early successional birds on powerline corridors. PLoS One, 7. doi: 10.1371/journal.pone.0031520

Banks-Leite C., Ewers R.M., Metzger J.-P. 2010. Edge effects as the principal cause of area effects on birds in fragmented secondary forest. Oikos, 119, 918-926.

Baranowska-Janota M., Rozenau-Rybowicz A. 2007. Korytarze ekologiczne w planowaniu przestrzennym. Problemy Rozwoju Miast, 1-2, 132-142.

Bücking W. 2003. Are there threshold numbers for protected forests? Journal of Environmental Management, 67, 37-45. 
Clarke D.J., White J.G. 2008. Towards ecological management of Australian powerline corridor vegetation. Landscape and Urban Planning, 86, 257-266.

Collinge S.K., Palmer T.M. 2002. The influences of patch shape and boundary contrast on insect response to fragmentation in California grasslands. Landscape Ecology, 17, 647-656.

Dołowy K., Kraszewski A., Różycki S. 2015. Linie elektroenergetyczne najwyższych napięć Informator dla administracji. Folder informacyjny. PSE SA.

Eldegard K., Totland Ø., Moe S.R. 2015. Edge effects on plant communities along power line clearings. Journal of Applied Ecology, 52, 871-880.

Ewers R.M., Didham R.K. 2008. Pervasive impact of large-scale edge effects on a beetle community. Proceedings of the National Academy of Sciences, 105, 5426-5429.

Forrester J.A., Leopold D.J., Hafner S.D. 2005. Maintaining critical habitat in a heavily managed landscape: Effects of power line corridor management on Karner blue butterfly (Lycaeides melissa samuelis) habitat. Restoration Ecology, 13, 488-498.

Fuentes-Montemayor E., Goulson D., Cavin L., Wallace J.M., Park K.J. 2013. Fragmented woodlands in agricultural landscapes: The influence of woodland character and landscape context on bats and their insect prey. Agriculture, Ecosystems and Environment, 172, 6-15.

Jędrzejewski W., Nowak S., Stachura K. et al. 2011. Projekt korytarzy ekologicznych łączących Europejską Sieć Natura 2000 w Polsce. Zakład Badania Ssaków PAN, Białowieża 2011.

Laurance W.F., Yensen E. 1991. Predicting the impacts of edge effects in fragmented habitats. Biological Conservation, 55, 77-92.

Li X., Lin Y. 2019. Do high-voltage power transmission lines affect forest landscape and vegetation growth: Evidence from a case for southeastern of China. Forests, 10, 1-13.

LIFE ELIA-RTE (2017) Vade-mecum: Vegetation management best practices for Transmission System Operators. http://www.life-elia.eu/en/Vade-mecum-Best-practices-for-Transmission-System-Operators

Mancebo Quintana S., Martín Ramos B., Casermeiro Martínez M.A., Otero Pastor I. 2010. A model forassessing habitat fragmentation caused by new infrastructure sinextensive territories evaluation of the impact of the Spanish strategic infrastructure and transport plan. J. Environ. Manage., 91(5), 1087-1096.

Nayak R., Karanth K.K., Dutta T., Defries R., Karanth K.U., Vaidyanathan S. 2020. Bits and pieces: Forest fragmentation by linear intrusions in India. Land Use Policy, 99, 1-12.

Plit J., Myga-Piątek U. 2014. The degree of landscape openness as a manifestation of cultural metamorphose. Quaestiones Geographicae, 33, 145-154.

Poikolainen T., Malinen J. 2020. Management of border zone forests in transmission line corridors. Baltic Forestry, 26, 1-10.

Porsius J.T., Claassen L., Smid T., Woudenberg F., Petrie K.J.,Timmermans D.R.M. 2015 Symptom reporting after the introduction of a new high-voltage power line: A prospective field study. Environmental Research, 138, 112-117.

Powell A.S., Lindquist E.S. 2011. Effects of Power-Line Maintenance on Forest Structure in a Fragmented Urban Forest, Raleigh, NC. Southeastern Naturalist, 10, 25-38.

Rich A.C., Dobkin D.S., Niles L.J. 1994. Defining forest fragmentation by corridor width: the influence of narrow forest dividing corridors on forest-nesting birds in Southern New Jersey. Conservation Biology, 8, 1109-1121.

Ries L., Fletcher R.J., Battin J., Sisk T.D. 2004. Ecological responses to habitat edges: mechanisms, models and variability explained. Annual Review of Ecology, Evolution, and Systematics, 35, 491-522.

Russell K.N., Ikerd H., Droege S. 2005. The potential conservation value of unmowed powerline strips for native bees. Biological Conservation, 124, 133-148. 
Villard M.A. 1998. On forest-interior species, edge avoidance, area sensitivity, and dogmas in a avian conservation. Auk, 115, 801-805.

Vogt P. 2018 User Guide of GuidosToolbox. Italy: European Commission Joint Research Centre (JRC), 1-58.

Vogt P., Riitters K. 2017. GuidosToolbox: Universal digital image object analysis. European Journal of Remote Sensing, 50, 352-361.

Xu K., Zhang X., Chen Z., et al. 2016. Risk assessment for wildfire occurrence in high-voltage power line corridors by using remote-sensing techniques: A case study in Hubei Province, China. International Journal of Remote Sensing, 37, 4818-4837.

Yildirim V., Nisanci R. 2010. Developing a Geospatial Model for Power Transmission Line Routing in Turkey. 25th FIG International Congress 2010, Sydney.

Dr hab. inż. Paweł Pieńkowski, prof. ZUT

West Pomeranian University of Technology in Szczecin

Faculty of Environmental Management and Agriculture

al. Piastów 17, 70-310 Szczecin

e-mail: ppienkowski@zut.edu.pl

ORCID: 0000-0002-6782-291X

Mgr inż. Marcin Stoltman

Biuro Dokumentacji Środowiskowej

ul. Metalowa 26B/6, 70-744 Szczecin

e-mail: stoltman.marcin@gmail.com

Prof. dr hab. inż. Bogusław Zakrzewski

West Pomeranian University of Technology in Szczecin

Faculty of Maritime Technology and Transport

al. Piastów 17, 70-310 Szczecin

e-mail: boguslaw.zakrzewski@zut.edu.pl

ORCID: 0000-0001-7907-363X 